\title{
Kompetensi Manajerial Kepala Sekolah dalam Meningkatkan Prestasi Non Akademik Siswa SMP
}

\author{
Karlina Yulista ${ }^{1}$, Yulia Tri Samiha ${ }^{2}$, Ahmad Zainuri ${ }^{3}$ \\ 1, 2, 3 UIN Raden Fatah, Palembang, Indonesia \\ yulistakarlina@gmail.com
}

\begin{abstract}
The purpose of this study was to find out how the students' non-academic achievement in the religious field of reading and writing al-quran and da'i / da'iyah. The type of research used is qualitative research. The research instrument used documentation, interviews, observation and triangulation. Then the data analysis used reduction, data presentation and data verification. The results of the study concluded that 1) planning, namely the principal carried out: formulating a vision and mission, compiling a strategic plan, compiling an annual activity plan and compiling an activity budget; 2) Student Management, namely: Management of Religious activities, Grouping and orientation, Guidance and reward systems / rewards for outstanding students; 3) Monitoring and evaluation includes: preventive supervision and collective supervision, and evaluation includes; student attendance and control books ; 4) The obstacles faced by the principal in improving students' non-academic achievement, namely; minimal funding, lack of spiritual guidance coordinators and undisciplined students participating in religious activities to read and write Al-Qur'an and da'i /da'iyah.
\end{abstract}

Keywords: competence, managerial, head of school, non academic achievement.

Abstrak. Tujuan dari penelitian ini untuk mengetahui bagaimana prestasi non akademik siswa pada bidang keagamaan baca tulis al-qur'an dan da'i/da'iyah. Jenis penelitian yang digunakan yaitu penelitian kualitatif. Insrumen penelitian menggunakan dokumentasi, wawancara, observasi serta triangulasi. Kemudian analisis data menggunakan reduksi, penyajian data dan verifikasi data. Hasil penelitian dapat disimpulkan bahwa 1) perencanaan yaitu kepala sekolah melakukan: perumusan visi dan misi, menyusun rencana strategi, menyusun rencana kegiatan tahunan dan menyusun anggaran kegiatan; 2) Pengelolaan Kesiswaan yaitu: Pengelolaan kegiatan Keagamaan, Pengelompokan dan orientasi, Pembinaan dan Sistem reward/penghargaan terhadap siswa yang berprestasi; 3) Pengawasan dan evaluasi mencakup: pengawasan preventif dan pengawasan kolektif, dan evaluasi mencakup; absensi dan buku kontrol siswa.; 4) Kendala yang dihadapi kepala sekolah dalam meningkatkan prestasi non akademik siswa yaitu; minim pendanaan, kurangnya tenaga Koordinator Pembina Rohis dan tidak disiplinnya siswa mengikuti kegiatan Keagamaan Baca Tulis Al-Qur'an dan da'i/da'iyah.

Kata Kunci: kompetensi, manajerial, kepala sekolah, prestasi non akademik.

\section{PENDAHULUAN}

Pendidikan merupakan investasi jangka panjang bagi kemajuan suatu Negara. Maju mundurnya suatu negara dipengaruhi oleh perkembangan pendidikan. Ini berarti sekolah sebagai lembaga pendidikan adalah wadah dalam mencetak generasi yang unggul dan berprestasi baik dari segi akademik maupun non akademik.

Tujuan Pendidikan berdasarkan Undang-Undang No. 20 Tahun 2003 Tentang Sistem Pendidikan Nasional dijelaskan untuk mengembangkan 
potensi peserta didik agar menjadi manusia yang beriman dan bertakwa kepada Tuhan yang Maha Esa berakhlak mulia, sehat, berilmu, cakap, kreatif, mandiri dan menjadi warga negara yang demokratis serta bertanggung jawab (Tolchah, 2015:54).

Kepala sekolah adalah orang yang paling bertanggungjawab dalam memajukan sekolah yang dipimpinnya. Kepemimpinan merupakan motor penggerak bagi sumber-sumber dan alat-alat baik yang bersifat "human resources" maupun "non human resources" dalam organisasi, sehingga dapat dianggap sukses tidaknya kegiatan organisasi itu sebagian besar ditentukan oleh kualitas pemimpin yang dimilki oleh orang-orang yang diserahi tugas dalam memimpin atau memenej organisasi itu dalam melaksanakan tugas kepemimpinannya, kepala sekolah tentunya harus memiliki dua kompetensi yaitu kompetensi dalam mengelola sumber daya manusia keahlian dalam mengerakan orang atau memenej bawahan untuk berkerja dengan efektif dan kemampuan teknisi dalam menyusun program sekolah (Purwanto, 2012: 67).

Permendiknas Nomor 13 tahun 2007 kompetensi yang harus dimiliki oleh setiap kepala sekolah yaitu: Kompetensi kepribadian, kompetensi manajerial, kompetensi kewirausahaan, kompetensi supervisi, dan kompetensi sosial. Unsur-unsur tentang kompetensi manajerial yang harus dimiliki kepala sekolah yaitu: 1) menyusun perencanaan sekolah/madrasah, 2) mengembangkan organisasi sekolah/madrasah sesuai dengan kebutuhan, 3) memimpin sekolah/madrasah dalam rangka pendayagunaan sumber daya sekolah secara optimal, 4) mengelola perubahan dan pengembangan sekolah menuju organisasi pembelajaran yang efektif, 5) menciptakan budaya dan iklim sekolah yang kondusif dan inovatif bagi pembelajaran peserta didik, 6) mengelola guru dan staf dalam rangka pendayagunaan SDM secara optimal, 8) mengelola hubungan sekolah dengan masyarakat dalam rangka pencarian dukungan ide, sumber belajar dan pembiayaan sekolah, 9) mengelola peserta didik dalam rangka penerimaan peserta didik baru, dan penempatan dan pengembangan kapasitas peserta didik, 10) mengelola pengembangan kurikulum dan kegiatan pembelajaran sesuai dengan arah dan tujuan pendidikan nasional, 11) mengelola keuangan sekolah sesuai dengan prinsip pengelolaan akuntabel, transparan, dan efesien, 12) mengelola ketatausahaan sekolah dalam mendukung mencapai tujuan sekolah/madrasah, 13) mengelola unit layanan khusus sekolah/madrasah dalam mendukung kegiatan pembelajaran dan kegiatan peserta didik disekolah, 14) mengelola sistem informasi sekolah dalam mendukung penyusunan program dan pengambilan keputusan, 15) memanfaatkan kemajuan teknologi informasi bagi peningkatan pembelajaran dan manajemen sekolah, 16) melakukan monitoring, evaluasi, dan pelaporan pelaksanaan program kegiatan sekolah/madrasah dengan prosedur yang tepat, serta merencanakan tindak lanjutnya (Amanah, R. 2018:3). Jadi dapat disimpulkan bahwa kompetensi manajerial adalah salah satu kompetensi yang harus di miliki oleh kepala sekolah. Selain itu, sebagai factor pendorong 
untuk mewujudkan visi, misi dan tujuan sekolah menuju sekolah yang bermutu, bermutu di segala bidang baik itu tenaga pendidik dan kependidikan, sarana dan prasarana, dan peserta didik.

Menurut Suryana (2004:1), kepala sekolah sebagai Key Person dalam peningkatan mutu sekolah, di sisi lain keterlibatan masyarakat dalam sekolah telah memperoleh peran yang cukup besar melalui wadah dewan sekolah. Secara operasional kepala sekolah adalah orang yang paling bertanggungjawab dalam merencanakan, mengkoordinasikan, menggerakkan, dan menyelaraskan semua sumberdaya (resources) sekolah serta dapat mengevaluasinya. Kepala sekolah merupakan faktor pendorong untuk mewujudkan visi, misi, tujuan dan sasaran sekolah yang dipimpinnya menuju sekolah yang bermutu, bermutu di bidang pelayanan, di bidang pembelajaran, di bidang sarana prasarana, profesionalisme guru, dan di bidang prestasi akademik dan non akademik.

Peningkatan kompetensi guru melalui sistem kepemimpinan kepala madrasah. Untuk mewujudkan kualitas sumber daya manusia yang profesional, kepala sekolah harus memiliki strategi yang tepat, pengawasan pendidikan, pendidikan dan pelatihan, pemberian motivasi terus, perubahan budaya kerja, sehingga elemen dasar pendidikan dapat terwujud. Kepala sekolah memilihi strategi untuk menjalin kerjasama dengan stakeholder (Fitriani, 2017). Sedangkan Setiyani (2017: 8) mengatakan bahwa kompetensi yang dimiliki kepala sekolah sangat bagus sebesar $85 \%$ meliputi bekerja sama, berpartisipasi dan memiliki kepedulian sosial. Kepala sekolah aktif dalam kegiatan sosial kemasyarakatan sehingga mempunyai peran sebagai leader sehingga membuat warga sekolah bersemangat untuk bersama-sama memajukan Lembaga sekolah (Setiyani, 2017:8).

Kepala sekolah sebagai manajer sangat membutuhkan tiga macam keterampilan manajerial yaitu keterampilan konsep, keterampilan teknik, dan keterampilan hubungan manusia. Alasan pentingnya keterampilan manajerial kepala sekolah yaitu kepala sekolah merupakan manajer yang menempati tiga jenjang yaitu: sebagai manajer tingkat atas dilingkup sekolah, sebagai manajer tingkat menengah dilingkup Dinas Pendidikan dan sebagai manajer tingkat bawah dilingkup Kementerian Pendidikan (Soedarmo, 2017:67).

Hasil penelitian Moedjiarto menyebutkan kepemimpinan kepala sekolah pada SMK Swasta di Surabaya yang tergolong unggul ternyata dinilai cukup baik dalam arti kepala sekolah mempunyai pemahaman yang baik terhadap visi dan misi sekolahnya, melaksanakan kontrol terhadap siswa dan proses pembelajaran dan para gurunya (Moedjiarto, 2000:43). Senada dengan hasil (Soedarmo \& Herman, 2017) bahwa kepala sekolah menjadi tolak ukur dalam keberhasilan sekolah, karena kepala sekolah di tuntut secara professional mengelola sekolah dalam hal menyusun visi, misi dan program sekolah sehingga untuk mencapai sebuah keberhasilan maka kepala sekolah harus memiliki kompetensi atau kemampuan mengelola segala sumber-sumber yang ada di sekolah dan kemampuan mengerakan para guru, 
staf dan stakeholder yang ada untuk bekerja sama dalam kemajuan sekolah.

Dalam penelitian ini, penulis mengambil lokasi di SMP Palembang. Pada observasi awal dilihat dari kenyataan bahwa SMP Palembang ini mempunyai banyak prestasi dalam bidang akademik dan non akademik. Namun, dalam prestasi non akademik pada bidang keagamaan di SMP Palembang masih di tingkat kota belum tembus tingkat provinsi maupun nasional.

Berdasarkan hasil observasi awal penulis penelitian ini hanya difokuskan pada tiga hal pokok yang secara dominan diperkirakan mempunyai kaitan erat dengan kompetensi manajerial kepala sekolah dalam meningkatkan prastasi non akademik siswa pada bidang keagamaan di SMP Palembang yaitu perencanaan manajerial kepala sekolah, pengelolaan kesiswaan, pengawasan, dan evaluasi kegiatan non akademik keagamaan. Karena luasnya penelitian ini maka berdasarkan Permendiknas No 13 Tahun 2007 Kompetensi Manajerial Kepala Sekolah memiliki 17 unsur kompetensi yang harus dimiliki oleh seorang kepala sekolah. Peneliti hanya membatasi pada penyelesaian masalah tentang perencanaan manajerial kepala sekolah, pengelolaan kesiswaan, pengawasan, dan evaluasi program kegiatan non akademik keagamaan di SMP Palembang. Adapun rumusan masalah dalam penelitian ini bagaimana kompetensi manajerial kepala sekolah dalam meningkatkan prestasi non akademik keagamaan (da'i/iyah dan Baca Tulis Al-Qur'an) siswa dan bagaimana kendala yang dihadapi kepala sekolah dalam meningkatkan prestasi non akademik keagamaan siswa di SMP Palembang.

\section{KAJIAN LITERATUR}

Kompetensi Manajerial Menurut wahyudi kompetensi adalah pengetahuan, keterampilan, dan nilai-nilai dasar yang direfleksikan dalam kebiasaan berfikir dan bertindak secara konsisten yang memungkinkannya menjadi kompeten atau kemampuan dalam menjalankan wewenang, tugas, dan tanggungjawabnya (Wahyudi, 2009:32). Sedangkan menurut Heidjrahman Ranupandojo dan Suad Husnan (2000:155) mengidentifikasikan kemampuan dengan keterampilan kerja yang terbentuk dari pendidikan dan latihan serta pengalaman kerja. Kompri (2017: 78) menyatakan bahwa kompetensi adalah kemampuan melaksanakan sesuatu yang diperoleh melalui pendidikan dan pelatihan. Kompetensi professional mengacu kepada perbuatan (Performance) yang bersifat rasional dan memenuhi spesifikasi tertentu dalam melaksanakan tugas-tugas kependidikan. Mengenai perangkat kompetensi professional dapat dilihat dari dua segi, yaitu profil kompetensi mengacu kepada berbagai aspek kompetensi yang dimiliki oleh seorang tenaga professional kependidikan. Kemudian spectrum kompetensi mengacu kepada variasi kualitatif dan kuantitatif perangkat kompetensi yang dimiliki oleh korps tenaga kependidikan yang dibutuhkan untuk mengoprasikan dan mengembangkan sistem Pendidikan. 
Manajerial berhubungan dengan manajer: suatu keterampilan yang tinggi sangat di perlukan dalam suatu perusahaan atau organisasi yang berhubungan dengan manajer atau pengelola. Manajer adalah orang yang berwenang dan bertanggung jawab membuat rencana, mengatur, memimpin, dan mengendalikan pelaksanaannya untuk mencapai sasaran tertentu. Manajemen dan manajer adalah ibarat dua sisi mata uang yang tidak bisa dipisahkan. Di mana ada manajemen maka di sana ada manajer. Manajemen adalah sistemnya sedangkan manajer adalah orang yang mengelolahnya (Ali M, 2020: 4).

Manajemen pada dasarnya merupakan suatu proses penggunaan sumber daya secara efektif dalam rangka mencapai sasaran atau tujuan tertentu. Dalam usaha mewujudkan tujuan pendidikan, manajemen merupakan faktor yang sangat penting. Oleh karena itu, agar supaya pendidikan dapat maju maka harus dikelola oleh manajer pendidikan yang profesional sehingga mewujudkan hasil belajar siswa yang memuaskan. Sehingga dapat dipahami bahwa pengelolaan pendidikan yang sukses adalah pengelolaan pendidikan yang mempunyai perencanaan yang baik, sehingga setiap pelaksanaan kegiatan tersebut mempunyai tujuan yang jelas, dengan demikian kepala sekolah bisa lebih efektif dan efisien dalam mengelola sekolah (Jafar, 2018:2).

George R. Tery mengatakan bahwa: dalam kombinasi fungsi fungdimental fungsi manajemen ada tiga fungsi yang sama, yaitu (a) perencanaan, (b) pengorganisasian dan pelaksanaan (c) pengawasan. Ada perbedaan tentang fungsi-fungsi lainnya. Misalnya, fungsi staffing sudah merupakan bagian dari organizing dan directing adalah sama dengan actuating atau motivating dan ada juga berkeyakinan bahwa innovating, refresenting, dan coordinating merupakan fungsi-fungsi yang fungdimental (Rusmawati, 2020: 4). Fungsi manajemen adalah elemen-elemen dasar yang selalu ada dan berada dalam proses manajemen yang menjadi patokan bagi manajer dalam melaksanakan kegiatan untuk mencapai tujuan (Arumi A, 2019:18).

Kepala sekolah adalah pimpinan pendidikan yang mempunyai peranan penting dalam mengembangkan lembaga pendidikan, yaitu sebagai pemegang kendali di lembaga pendidikan. Sejalan dengan itu, peranan kepala sekolah sangat berpengaruh dalam pertumbuhan dan perkembangan pendidikan yakni untuk meningkatkan sumber daya manusia dan mutu pendidikan (Rosyadi, 2015:2).

Ketercapaian tujuan pendidikan sangat bergantung kepada kecakapan dan kebijaksanaan kepemimpinan kepala sekolah yang merupakan 
pemimpin pendidikan di sekolah. Kepala sekolah adalah seorang pejabat yang professional dalam organisasi sekolah. Kepala sekolah bertugas mengatur semua sumber organisasi dan bekerjasama dengan guruguru dalam mendidik siswa untuk mencapai tujuan pendidikan. Dengan keprofesionalan kepala sekolah pengembangan profesionalisme tenaga kependidikan mudah dilakukan karena sesuai dengan fungsinya. Kepala sekolah memahami kebutuhan sekolah yang dipimpin sehingga kompetensi guru tidak hanya bertumpu pada kompetensi yang ia miliki sebelumnya, melainkan bertambah dan berkembang dengan baik sehingga profesionalisme guru akan berhasil (Yahdiyani, 2020; 1).

Kepemimpinan diartikan sebagai suatu cara dan metode seseorang yang dapat mempengaruhi orang lain sedemikian rupa sehingga orang tersebut dengan sadar mengikuti dan mematuhi segala kehendaknya. (Maduratna, 2013:72). Dalam kepemimpinan, pola sangat mempengaruhi upaya peningkatan kualitas dan produktivitas dalam segala bidang, baik dalam sistem menejemen yang akan dikembangkan (Ekosiswoyo, 2007:5).

Kepala sekolah sebagai manajer, mempunyai fungsi: menyusun perencanaan, mengkoordinasikan kegiatan, melakukan pengawasan, melakukan evaluasi terhadap kegiatan, mengadakan rapat, mengambil keputusan, mengatur proses pembelajaran, mengatur administrasi, dan mengatur tata usaha, siswa, ketenagaan, sarana, dan prasarana, keuangan (Fitrah, 2017:37).

Kepala Sekolah sebagai pemimpin pendidikan yang di Sekolah harus mempunyai penampilan atau kinerja kepemimpinan yang baik, dimana yang dimaksud dengan kinerja adalah kinerja merupakan kegiatan pengelolaan sumber daya organisasi untuk mencapai tujuan organisasi. Tujuan kinerja adalah menyesuaikan harapan kinerja individual dengan tujuan organisasi, kesesuaian antara upaya pencapaian tujuan individu dengan tujuan organisasi akan mampu mewujudkan kinerja yang baik. Singkatnya yang dimaksud dengan kinerja dalam konteks pendidikan ialah prestasi, kontribusi atau hasil kerja pendidikan yang dapat terukur. Jadi yang dimaksud dengan kompetensi manajerial kepala sekolah adalah seperangkat kemampuan yang harus ada dalam diri kepala sekolah agar dapat mewujudkan keterampilan unjuk kerja sebagai kepala sekolah dalam menjalankan visi dan misi sekolah yang dipimpinnya berdasarkan keterampilan dan kemampuan yang dimilikinya (Nurussalami, 2015:12).

Peserta didik merupakan salah satu komponen pendidikan. Menurut pasal 1 ayat 4 UU RI No. 20 Tahun 2003 tentang sistem pendidikan Nasional, peserta didik adalah anggota masyarakat yang berusaha mengembangkan 
dirinya melalui proses pendidikan pada jalur jenjang dan jenis pendidikan tertentu. Tetapi, pada hakikatnya semua manusia adalah peserta didik. Sebab, pada hakikatnya, semua manusia adalah makhluk yang senantiasa berada dalam proses perkembangan menuju kesempurnaan, atau suatu tingkatan yang dipandang sempurna, dan proses itu berlangsung sepanjang hayat (Maghfiroh, 2012:5).

Prestasi non Akademik Siswa Menurut Mulyono dalam bukunya prestasi non akademik adalah "prestasi atau kemampuan yang di capai siswa dari kegiatan diluar jam atau dapat disebut dengan kegiatan ekstrakurikuler (Mulyono, 2008:188). Kegiatan ekstrakurikuler adalah berbagai kegiatan sekolah yang dilakukan dalam rangka memberikan kesempatan kepada pesert didik untuk dapat mengembangkan potensi, minat, bakat, dan hobi yang dimilikinya yang dilakukan diluar jam sekolah normal (Mulyono, 2008:189).

Menurut Lutan kegiatan ekstrakurikuler merupakan bagian internal dari proses belajar yang menekankan pada pemenuhan kebutuhan anak didik (Rusli, 1986:72). Sedangkan menurut Heri (2012: 258) kegiatan ekstrakurikuler adalah kegiatan pendidikan yang dilakukan diluar jam pelajaran tatap muka. Jadi dapat disimpulkan bahwa prestasi non akademik adalah hal-hal yang bersifat natural dan tidak terpaku pada suatu teori tertentu. Lain halnya prestasi akademik, kemampuan non akademisi seseorang sulit diukur secara pasti karena tidak ada salah dan benar di dalamnya. Jadi peserta didik dikatakan berprestasi dikarenakan berhasil mencapai sesuatu bisa pencapaian secara individu maupun kelompok yang memenuhi standar baik itu berprestasi pada bidang akademik maupun non akademik.

\section{METODE PENELITIAN}

Metode penelitian yang digunakan peneliti yaitu Penelitian kualitatif. Di mana peneliti kualitatif bertujuan untuk menemukan jawaban terhadap suatu phenomena atau suatu masalah yang menarik perhatian, dengan cara sistematis serta disajikan dalam bentuk naratif. Dengan penelitian kualitatif ini diharapkan penelitian tentang Kompetensi Manajerial kepala sekolah dalam meningkatkan prestasi non akademik siswa dalam bidang keagamaan yang meliputi perencanaan kepala sekolah dalam meningkatkan prestasi non akademik siswa bidang keagamaan, pengelolaan kesiswaan, pengawasan dan evaluasi kegiatan non akademik keagamaan di SMP Palembang kemudian kendala apa saja yang di hadapi kepala sekolah dalam meningkatkan prestasi non akademik keagamaan siswa di SMP Palembang. 
$\overline{\text { Selanjutnya phenomena atau objek masalah tersebut dibahas secara ilmiah }}$ yaitu bersifat rasional, empiris dan sistematis.

Penelitian ini dilakukan di SMP Palembang terletak ditengah Kota Palembang Provinsi Sumatra Selatan. Tepatnya di Jalan Rudus Skip Ujung Kelurahan 20 Ilir II kecamatan Ilir Timur di wilayah Kota Palembang. Alasan memilih SMP Palembang karena tempatnya strategis di tengah Kota Palembang mudah dijangkau untuk melakukan penelitian. Selain itu peneliti tertarik karena SMP Palembang walaupun bukan dari sekolah berbasis agama seperti madrasah Tsanawiyah atau pondok pesantren melainkan sekolah umum tapi sekolah ini mempunyai prestasi di bidang keagamaan Islam seperti lomba daiyah juara 1, 23 tingkat kota. Penelitian ini menggunakan teknik pengumpulan data: observasi, wawancara, dokumentasi dan triangulasi data dan analisis data yang terdiri dari tiga tahapan aktivitas yaitu: reduksi data, tampilan data, dan gambar kesimpulan atau verifikasi (Miles \& Hubermen, 1984: 10).

\section{HASIL DAN PEMBAHASAN}

Kepala sekolah adalah tokoh sentral dalam memajukan sekolah, berhasil atau tidaknya sebuah lembaga pendidikan khususnya pada satuan pendidikan akan sangat dipengaruhi oleh kompetensi yang dimiliki kepala sekolah tersebut, Peraturan Menteri Pendidikan Nasional Nomor 13 Tahun 2007 bahwa Kompetensi Kepala Sekolah harus memiliki lima kompetensi minimal yaitu; kompetensi keperibadian, kompetensi manajerial, kompetensi kewirausahaan, kompetensi supervisi dan kompetensi social.

Kompetensi Manajerial adalah Kemampuan mengendalikan seluruh sumber daya dalam satuan pendidikan untuk mencapai visi, dan misi, serta tujuan satuan pendidikan (Kompri, 2012:109).

Kompetensi manajerial kepala sekolah dalam meningkatkan prestasi non akademik siswa di SMP Palembang. Kompetensi manajerial kepala sekolah di lihat dari beberapa aspek kompetensi yang dalam hal ini peneliti membatasi dalam aspek penyusunan perencanaan, pengelolaan siswa, pengawasan dan evaluasi kegiatan non akademik keagamaan di SMP Palembang. Pendidikan formal tertinggi kepala sekolah SMP Palembang adalah Magister Sains (M.Si) secara akademisi sesuai dengan bidang 
pendidikan dan dapat menunjang kemampuannya dalam menjalankan tugas sebagai manajer di sekolah.

Dari sebagian hasil wawancara yang dilakukan peneliti kepada kepala sekolah (KS) bahwa kepala sekolah telah berusaha semaksimal mungkin agar siswa-siswi SMP Palembang ini berprestasi bukan hanya bidang akademik tapi juga bidang non akademik sesuai dengan visi SMP Palembang yaitu unggul dalam IMTAK. Kepala sekolah SMP Palembang ini sudah menjabat pada tahun 2015 kurang lebih empat tahun lebih dan sudah banyak prestasi yang diperoleh baik tingkat kota sampai tingkat provinsi.

Kemudian peneliti bertanya lagi kepada kepala sekolah pelatihanpelatihan atau kegiatan-kegiatan apa saja yang pernah diikuti kepala sekolah. Adapun pelatihan-pelatihan yang pernah diikuti kepala sekolah SMP Palembang adalah Pelatihan kepemimpinan kepala sekolah, Sosialisasi kurikulum, Membentuk kelompok kerja sekolah, Sosialisasi keuangan BOS, Pelatihan pengguatan kepala sekolah, Penelaan Pelatihan USBN dan lain sebagainya.

Di SMP Palembang Prestasi lembaga, guru dan juga siswa-siswi adalah salah satu bukti keberhasilan dari sistem kerjasama dan kompetensi yang dimiliki oleh kepala sekolah, guru, staf dan karyawan serta proses belajar mengajar di sekolah sehingga menghasilkan prestasi. SMP Palembang juga ikut berkontribusi dalam event perlombaan tingkat kota dan provinsi. Tidak hanya dalam kompetisi lembaga, integritas dan kemampuan yang dimilki oleh pendidik, akademik siswa/siswi, juga kegiatan ekstrakurikulernya. Prestasi yang diraih tersebut, pasti tidak di dapat dengan mudah ada proses pendidikan yang dilalui ini terlihat dari usaha pembinaan yang lakukan oleh kepala sekolah. Kompetensi, keterampilan dan skil yang diberikan SMP Palembang, untuk menjadikan siswa menjadi kreatif dan berpengetahuan sehingga dapat berprestasi. Siswa di SMP Palembang selain proses belajar di kelas, siswa juga mendapatkan pembinaan kegiatan pengembangan diri yang berbentuk kegiatan ekstrakurikuler di luar jam pelajaran. Prestasi-prestasi 
dan penghargaan yang dirahi inilah yang menjadikan SMP Palembang menjadi prioritas dan kepercayaan masyarakat sekitar sekolah untuk didik dan mengajarkan anak-anak mereka setelah menyelesaikan jenjang Sekolah Dasar.

Kompetensi manajerial kepala sekolah dalam meningkatkan prestasi non akademik siswa di SMP Palembang:

1. Perencanaan Kepala Sekolah dalam Meningkatkan Prestasi non akademik keagamaan (Da'i/Da'iyah, Baca Tulis Al-Qur'an) siswa di SMP Palembang. Perencanaan sekolah yang dimulai dengan penyusunan visi sampai rencana kerja tahunan sekolah serta kegiatan tahunan (Kompri, 2017:110).

Adapun kompetensi manajerial kepala sekolah dalam aspek perencanaan program kegiatan dalam meningkatkan prestasi non akademik keagamaan (Da'i/Da'iyah, Baca Tulis Al-Qur'an ) siswa di SMP Palembang.

a. Perumusan visi dan Misi kegiatan non akademik keagamaan

Visi dan misi adalah landasan pertama dalam merumuskan perencanaan, visi merupakan gambaran masa depan organisasi, dia berfungsi sebagai pemberi arahan dan motivasi bagai para anggotanya. Sedangkan misi adalah cara untuk mencapai visi dia berperan untuk mengenalkan para anggota organisasi terhadap peran dan fungsi mereka.

Di SMP Palembang perumusan Visi dan Misi kegiatan keagamaan tertuang pada visi dan misi secara umum, diketahui visi SMP Palembang yaitu unggul dalam IMTAQ tujuan nya menjadikan sekolah yang siswa-siswanya bukan hanya cerdas secara intelektual tetapi cerdas secara spiritual. Oleh karena itu, kepala sekolah berupaya mengajak para wakil dan staf serta warga sekolah untuk bisa bekerja sama dalam menjadikan sekolah berpretasi baik pada bidang akademik dan non-akademik.

Proses penyusunan program kerja sekolah di SMP Palembang, dilakukan setiap awal tahun ajaran baru di adakan rapat kerja sekolah dengan melibatkan kepala sekolah, para wakil kesiswaan, kurikulum, guru, staf dan komite membahas program kerja. Adapun penyusunan rencana program kegiatan keagamaan di SMP Palembang program kegiatan keagamaan juga masuk dalam: perencanaan jangka panjang, menengah, dan pendek. Untuk jangka pendek program perencanaan 
satu tahun membahas bagaimana kegiatan yang di lakukan satu tahun kedepan misal target satu tahun kedepan siswa minimal menghatamkan 10 juz, dua tahun kedepan 20 juz dan 3 tahun ketika siswa sudah tamat maka siswa harus menyelesaikan 30 juz Al-Qur'an dengan mengeluarkan seterfikat hatam Qur'an yang nantinya akan berguna bagi siswa untuk melanjutkan jenjang selanjutnya. Kemudian pada program da'i/da'iyah di SMP Palembang kegiatan ini tujuannya mewadahi bagi siswa/siswi yang memiliki bakat dan minat di bidang da'i karena menurut keterangan kepala sekolah siswa/siswi di sini banyak tertarik dalam kegiatan ini maka dibuatlah program kegiatan da'i/da'iyah.

b. Menyusun rencana strategi kegiatan Keagamaan BTQ dan da'i/da'iyah Dalam menyusun renstra itu pertama kita harus membuat misi, kemudian mengidentifikasi tujuan yang akan menghantarkan kepada visi, dan kemudian menentukan sasaran yang akan membantu dalam merahi tujuan. adapun rumusan strategi kegiatan keagamaan BTQ dan da'i/da'iyah di SMP Palembang yaitu; (1) mengadakan, mengarahkan serta membina bakat dan minat siswa; (2) membuat rancangan kegiatan yang dibantu oleh pembina rohis, para guru dan staf; (3) mengadakan perlombaan atau mengikuti perlombaan mengasah bakat dan minat siswa.

c. Menyusun rencana kegiatan tahunan Keagamaan

Kegiatan sekolah dilaksanakan berdasarkan rencana kerja tahunan dan diaksanakan oleh penanggungjawab kegiatan yang didasarkan pada ketersediaan sumber daya yang ada dan harus mendapat persetujuan melalui rapat dewan pendidik dan komite sekolah.

d. Menyusun anggaran kegiatan non akademik keagamaan

Dalam kegiatan perencanaan tahap selanjutnya yaitu pendanaan untuk kegiatan atau anggran belanja sekolah (RAPBS). Pendanaan untuk program kegiatan keagamaan ini di ambil dari dana BOS, untuk intensif guru Pembina rohis dan anggotanya, dan uang teransportasi keluar jika sedang ikut lomba. Adapun untuk pendanaan dalam kegiatan keagamaan ini kepala sekolah menggunakan anggaran belanja sekolah untuk kegiatan mengaji atau uang intensif kepada para pembina, uang transportasi dan lain sebagainya.

Perencanaan yang baik, menuntut pelibatan semua stakeholder sekolah, seperti: kepala sekolah, guru, staf, peserta didik, pengawas orangtua/komite sekolah, dan dewan pendidikan (Mulyasa, 2012: 62). Adapun di SMP Palembang ini peran kepala sekolah cukup baik, dalam 
kompetensi manajerial aspek perencanaan sekolah, dengan merumuskan visi misi melibatkan stakeholdernya ketika rapat serta membagi tugas sesuai dengan kompetensi dan tanggung jawab masing, Penyusunan strategi kegiatan, serta penyusunan anggaran kegiatan telah terlaksana dan memenuhi criteria pedoman penyusunan perencanaan sekolah.

2. Pengelolaan Kesiswaan di SMP Palembang dalam meningkatkan prestasi non akademik keagamaan (Da'i/Da'iyah, Baca Tulis Al-Qur'an)

Menurut Suhardan, dkk. (2010), yang dikutip Kompri, tujuan manajemen kesiswaan adalah mengatur kegiatan siswa agar kegiatan-kegiatan tersebut menunjang proses pembelajaran di lembaga pendidikan. Proses pembelajaran di lembaga tersebut dapat berjalan lancar, tertib, dan teratur sehingga dapat memberikan kontribusi bagi pencapaian tujuan sekolah dan pencapaian tujuan pendidikan secara keseluruhan (Kompri, 2017:138).

Adapun kompetensi manajerial kepala sekolah dalam aspek pengelolaan kesiswaan dalam meningkatkan prestasi non akademik keagamaan (Da'i/Da'iyah, Baca Tulis Al-Qur'an) siswa di SMP Palembang:

a. Pengelolaan peserta didik baru dalam kegiatan non akademik keagamaan

Pengelolaan kesiswaan sebagai usaha pengaturan peserta didik dari mulai masuk sekolah sampai mereka lulus sekolah. Adapun prinsip yang perlu diperhatikan oleh kepala sekolah dalam pelaksanaannya harus mengacu pada peraturan yang berlaku pada saat program dilaksanakan.

Berdasarkan hasil penelitian dan analisis data, Kegiatan pengelolaan peserta didik baru dalam kegiatan non akademik keagamaan di SMP Palembang yaitu kepala sekolah berusaha menganalisa kebutuhan sekolah termasuk mengenal bakat dan potensi apa saja yang mesti dikembangkan siswa. Untuk mengetahui bakat, minat serta untuk mencapai visi secara umum yaitu unggul dalam Imtak maka sekolah membuat program kegiatan non akademik keagamaan BTQ dan Da'i/Da'iyah di SMP Palembang.

Ternyata kegiatan keagamaan BTQ sudah berjalan 3 tahun. Target kepala sekolah, ketika tamat atau sudah lulus sekolah siswa sudah hatam Al-Qur'an 30 Juz dan mendapat sertifikat dari sekolah, sertifikat tersebut bisa digunakan oleh siswa ketika melanjutkan SMA nanti. Menurut pengamatan di lapangan program BTQ ini di buat untuk kebermanfaat siswa di luar nanti selain sertifikat yang bisa di gunakan 
untuk melanjutkan jenjang SMA banyak sekolah mensyaratkan siswa baru punya sertifikat BTQ maka biasanya akan diprioritaskan. Selain itu ilmu yang di dapat jauh lebih berguna untuk kehidupan siswa kelak dalam bidang keagamaannya nanti.

b. Pengelolaan pengelompokan siswa dalam kegiatan non akademik keagamaan

Dalam kegiatan non akademik siswa biasanya dikelompokkan berdasarkan pada bakat, minat, kemampuan, dan sebagainya. Kemudian bagi siswa baru orientasi atau pengenalan terhadap situasi dan kondisi sekolah dalam hal lingkungan fisik, lingkungan social dan kegiatan - kegiatan yang ada di sekolah tempat siswa tersebut menempuh pendidikan.

Sistem pengelompokan dan orientasi di SMP Palembang yang pertama memperkenalkan lingkungan sekolah tujuannya supaya siswa mencintai lingkungan, menjaga lingkungan dan melestarikan lingkungan. Kemudian dalam kegiatan non akademik keagamaan BTQ siswa/siswi dikelompokan berdasarkan tingkat bisa baca Al-Qur'an akan masuk kelas tahfiz atau tilawah. Kemudian untuk siswa yang belum pasih baca Al-Qur'an maka masuk kelas tahsin. Kemudian untuk kegiatan da'i/da'iyah kegiatan ini di kelompokan berdasarkan minat dan bakat anak itu sendiri yang kegiatannya di laksanakan setiap satu bulan sekali setiap dua minggu sekali pada hari Jum'at anak dibiasakan tampil di lapangan untuk bertausiyah secara bergiliran tujuanya untuk memberi ruang gerak pada anak yang punya kecenderungan ingin mengembangkan potensi da'i/da'iyahnya. Kegiatan ini punya kelompok dan ada pembimbingnya yaitu dari Pembina rohis sekolah.

c. Pembinaan kegiatan akademik keagamaan

Pembinaan peserta didik adalah kegiatan menumbuhkembangkan potensi, bakat dan minat siswa seoptimal mungkin melalui kegiatan kurikuler dan ekstrakurikuler dan pembinaan ini diukur melalui proses penilaian yang dilakukan oleh sekolah.

Pembinaan kegiatan keagamaan disini kepala sekolah menugaskan wakil kesiswaa, Pembina rohis untuk bersinergi dengan cara menjalankan program, mengadakan pelatihan kepada siswa, dan mendatangkan da'i dari luar seperti kegiatan da'i kepala sekolah pernah mendatangkan ustad untuk berceramah di SMP Palembang, tujuannya untuk memotivasi siswa supaya lebih semanggat dalam memaksimalkan potensi siswa pada bidang keagamaan. Kemudian dampak dari pembinaan tersebut ketika siswa mengikuti lomba di luar 
sekolah mereka sering mendapat juara pada lomba memperingati harihari besar Islam seperti lomba da'i cilik pada tahun 2018 lalu.

d. Sistem reward atau penghargaan terhadap siswa yang berprestasi Reward atau penghargaan biasanya diberikan kepada siswa baik secara individu atau kelompok yang berprestasi karena mendapat nilai bagus atau mendapakan juara dalam perlombaan di sekolah atau diluar sekolah.

Adapun berdasarkan hasil penelitian di lapangan sistem reward/penghargaan di SMP Palembang bersifat moril maupun materil. Penghargaan yang bersifat moril seperti bentuk motivasi yang di berikan oleh kepala sekolah sebagai apresiasi terhadap siswa yang berprestasi, biasanya jika siswa memenangkan sebuah perlombaan misal lomba da'i cilik nanti akan di umumkan pada saat upacara dilapangan hal ini bertujuan untuk memotivasi siswa yang lain untuk berprestasi. Kemudian reward yang bersifat materil anak yang berprestasi tersebut bebas uang komite selama 3 bulan dan akan diprioritaskan atau mempermudahkan siswa tersebut untuk masuk SMA unggulan.

3. Pengawasan dan evaluasi Program Kegiatan non akademik keagamaan (da'i/da'iyah, Baca Tulis Al-Qur'an) siswa di SMP Palembang

a. Pengawasan Kegiatan non akademik keagamaan (da'i/da'iyah, Baca Tulis Al-Qur'an) siswa di SMP Palembang.

Kunci penting dari proses manajemen sekolah, yaitu nilai fungsi manajemen terletak terutama pada hubungannya terhadap perencanaan dan kegiatan-kegiatan yang didelegasikan. Pengawasan dapat diartikan sebagai proses kegiatan monitoring untuk menyakinkan bahwa semua kegiatan organisasi terlaksana seperti yang direncanakan dan sekaligus juga merupakan kegiatan untuk mengkoreksi dan memperbaiki bila ditemukan adanya penyimpangan yang akan mengganggu pencapaian tujuan (Kompri, 2017:169).

Sistem pengawasan program kegiatan di SMP Palembang bersifat preventif dan kolektif yaitu: Pengawasan preventif di SMP Palembang bersifat pencegahan kalau seandainya terjadi penyimpangan terhadap program kegiatan dengan cara menginggatkan dan memotivasi para guru, staf, karyawan dan siswa sehingga mereka semanggat dalam menjalankan program dan penyimpangan itu bisa di minimalisir. Misalnya mengingatkan Pembina rohis untuk aktif dalam menjalankan program rumah Al-Qur'an dan kegiatan da'i/da'iyah latihan secara intensif ketika beberapa hari sebelum ikut lomba. 
Sedangkan Pengawasan korektif adalah kegiatan pengendalian yang dilakukan untuk memperbaiki kondisi jika terdapat suatu permasalahan yang menyebabkan resiko tidak tercapainya tujuan organisasi, yang telah ditemukan pada kegiatan pengendalian preventif maupun detektif. Kegiatan Korektif relatif lebih mahal dari kegiatan peventif maupun detektif.

Adapun pengawasan korektif di SMP Palembang yaitu dilaksankaan jika sudah terjadi penyimpangan terhadap program dan sejauh ini program kegiatan non akademik keagamaan berjalan dengan efektif ini dikarenakan kepala sekolah sudah melakukan pengawasan secara preventif atau pengawasan yang bersifat pencegahan suatu masalah atau resiko bisa di minimalisir.

4. Evaluasi Kegiatan non akademik keagamaan (Da'i/Da'iyah, Baca Tulis AlQur'an) siswa di SMP Palembang.

Evaluasi dilakukan sebagai tindakan untuk mengukur tingkat keberhasilan suatu program pelajaran atau kegiatan yang telah dilaksanakan. Pelaksanaan evaluasi di SMP Palembang berjalan dengan baik dan lancar.

Sistem evalusi di SMP Palembang evaluasi di laksanakan setiap semester artinya dua kali dalam setahun. Ada beberapa aspek yang dinilai dalam kegiatan non akademik keagamaan di SMP Palembang yaitu absensi, praktek kegiatan dan perilaku siswa dapat di simpulkan sebagai berikut:

a. Absensi siswa

Dalam kegiatan non akademik keagamaan di SMP Palembang hal utama yang dilakukan adalah absensi. Dimana absensi merupakan hal yang penting dalam proses kegaiatan belajar mengajar, karena absensi mengetahui siapa yang mengikuti kegiatan non akademik keagamaan maupun yang tidak mengikuti. Absen sangat penting bagi kepala sekolah dan Pembina kegiatan keagamaan, absen adalah catatan dalam pelaksanaan bahwa mengikuti kegiatan BTQ atau kegiatan da'i/da'iyah.

b. Buku control

Adapun untuk mengetahui bahwa siswa sudah mengikuti materi atau sudah sampai di Jus berapa maka di perlukan buku control Baca AlQur'an, setiap kelas harus memiliki buku control bacaan Al-Qur'an yang nantinya setiap akhir semester di kumpul kepada Wakil kesiswaan atau Pembina kegiatan non akademik.

5. Kendala Kompetensi Manajerial kepala sekolah dalam meningkatkan kegiatan non akademik keagamaan 
Kamus Besar Bahasa Indonesia (2008:667) mendefinisikan pengertian kendala adalah halangan rintangan dengan kendala yang membatasi, menghalangai atau mencegah pencapaian sasaran.

Menurut kepala sekolah SMP Palembang Ibu Hastia menyatakan tidak ada kendala yang signifikan dalam membuat dan menjalankan program kegiatan non akademik keagamaan di SMP Palembang.

Namun dalam hal ini ada beberapa kendala yang dihadapi kepala sekolah dalam meningkatkan kegiatan non akademik Baca Tulis Al-Qur'an dan da'i/da'iyah ada beberapa hal penemuan di lapangan yaitu:

a. Minim Pendanaan

Minimnya dana untuk kegiatan keagamaan karena sumber pendanaan hanya dari dana BOS. hal ini menjadi kendala karena SMP Palembang akhirnya mengurangi kegiatan keagamaan untuk menekan dana kegiatan mengingat sumber dana sekolah terbatas hanya dari bantuan operasional sekolah (BOS).

b. Kurangnya guru PAI

Masih kurangnya tenga SDM guru PAI hal ini terlihat pada tugas dan fungsi Pembina rohis dalam kegiatan rumah Al-Qur'an yang merupakan bagian dari kegiatan keagamaan BTQ disini satu coordinator rohis merangkap menjadi coordinator hafis Al-Qur'an, Tilawah dan tahsin, begitu juga coordinator Da'i/Da'iyah juga merangkap menjadi coordinator tilawah dan tahsin. Bahkan SMP Palembang menarik guru umum seperti guru IPA yang memiliki kecenderungan dan bersedia membantu kegiatan keagamaan dan akhirnya dilibatkan hal ini di sebabkan karena kurangnya guru PAI di SMP Palembang.

c. Tidak disiplinnya Siswa mengikuti kegiatan

Banyak siswa yang belum disiplin dalam mengikuti kegiatan keagamaan seperti ketika jam ke nol atau kegiatan keagamaan Baca Tulis Al-Qur'an ada siswa yang terlambat mengikuti kegiatan keagamaan, bolos ke kantin dan lain sebagainya.

\section{KESIMPULAN}

Perencanaan Kepala Sekolah dalam Meningkatkan Prestasi non akademik keagamaan (Da'i/Da'iyah, Baca Tulis Al-Qur'an) siswa di SMP Palembang; tercermin dalam Perumusan visi dan Misi, Menyusun rencana strategi, Menyusun rencana kegiatan tahunan dan Menyusun anggaran kegiatan. 
Pengelolaan Kesiswaan di SMP Palembang dalam meningkatkan prestasi non akademik keagamaan (Da'i/Da'iyah, Baca Tulis Al-Qur'an); Pengelolaan kegiatan Keagamaan, Pengelompokan dan orientasi peserta didik kegiatan BTQ dan Da'i/Da'iyah, Pembinaan dalam kegiatan BTQ dan Da'i/Da'iyah dan Sistem reward/penghargaan terhadap siswa yang berprestasi. Pengawasan dan evaluasi Program Kegiatan non akademik keagamaan (Da'i/Da'iyah, Baca Tulis Al-Qur'an) siswa di SMP Negeri 9 Palembang; Pengawasan bersifat; preventif dan korektif. Sedangkan Evaluasi meliputi Absensi siswa dan Buku control kegiatan keagamaan. Kendala yang dihadapi kepala sekolah dalam meningkatkan prestasi non akademik keagamaan yaitu: minim pendanaan, kurangnya tenaga coordinator rohis dan tidak disiplinnya siswa.

\section{DAFTAR PUSTAKA}

Ali, M. (2020). Fungsi Manajerial Kepala Sekolah dalam Mewujudkan Program Keagamaan. Studi Manageria: Jurnal Manajemen Pendidikan Islam, 2(1).

Amanah, R. (2018). Kompetensi Kepala Sekolah Dalam Meningkatkan kinerja guru di SD Muhammadiyah 07 Randudongkal Pemalang Tahun 2018. Jurnal Eprints UMS.

Arumi, A. (2019). Manajemen Ekstrakulikuler Kerohanian Islam di Sekolah Menengah Atas (SMA) Palembang. Studi Manageria Jurnal Manajemen Pendididkan Islam, 1(2).

Baharun, H. (2017). Peningkatan kompetensi guru melalui sistem kepemimpinan kepala madrasah. At-Tajdid: Jurnal Ilmu Tarbiyah, 6(1).

Ekosiswoyo, R. (2007). Kepemimpinan Kepala Sekolah Yang Efektif Kunci Pencapaian Kualitas Pendidikan. Jurnal Ilmu Pendidikan, 14, (2).

Fitrah, M. (2017). Peran Kepala Sekolah Dalam Meningkatkan Mutu Pendidikan. Jurnal Penjaminan Mutu, 3(1).

Fitriani, C., Murniati, Usman, N. (2017). Kompetensi Profesional Guru dalam Pengelolaan Pembelajaran di MTs Muhammadiyah Banda Aceh. Jurnal Magister Administrasi Pendidikan, 5 (2), 88-95.

Heri, G. (2012). Pendidikan Karakter: Konsep dan Implementasi. Bandung: Alfabeta.

Jafar, Z., Yusrizal, \& Khairuddin. (2018). Kinerja Guru Pada SMP ISLAM Terpadu Al-Fityan Kabupaten Aceh Besar. Jurnal Administrasi Pendidikan, 6 (1), 36-44.

Kompri. (2017). Standarisasi Kompetensi Kepala Sekolah. Jakarta: Kencana. 
Maduratna, M. (2013). Peranan Kepemimpinan Kepala Sekolah Dalam Meningkatkan Efektivitas Kerja Guru Dan Pegawai Di Sekolah Dasar Negeri 015 Samarinda. Jurnal Administrasi Negara, 1(1), 70-84.

Maghfiroh, L. (2019). Hakikat Pendidik dan Peserta Didik dalam Pendidikan Islam. MIDA: Jurnal Pendidikan Dasar Islam, 2(2).

Miles, M.B dan Huberman, A.M. (1984). An Expended Soure Book Quality Data Analsis. London: Sage Publication.

Moedjiarto. (2000). Kompetensi Manajerial Kepala Sekolah dalam Meningkatkan Kualitas Sekolah. Jurnal Unair , 9.

Mulyasa. (2012). Praktek Penelitian Tindakan Kelas. Bandung: PT Remaja Rosdakarya.

Mulyono. (2008). Managemen Administrasi \& Organisasi. Jogjakarta: Bumi Askara.

Nurussalami. (2015). Kompetensi Manajerial Kepala Sekolah dalam Meningkatkan Kinerja Guru DI MTsN Tungkop. Jurnal Ilmiah Circuit, $1(1)$.

Purwanto, N. (2012). Administrasi Supervisi Pendidikan. Bandung: PT Remaja Rosdakarya.

Ranupandojo \& Husnan. (2000). Manajemen Personalia. Jogjakarta: BPFE.

Rosyadi, Y.I., \& Pardjono. (2015). Peran Kepala Sekolah Sebagai Manajer dalam Meningkatkan Mutu Pendidikan di SMP 1 Cilawu Garut. Jurnal Akuntabilitas Manajemen Pendidikan, 3(1).

Rusli, L. (1986). Pengelolaan Interaksi Belajar Mengajar Intrakurikuler Kokurikuler dan Ekstrakurikuler. Jakarta: Karunia.

Rusmawati. (2020). Kompetensi Manajerial Kepala Sekolah dalam Pelaksanaan Ujian Nasional Berbasis Computer (UNBK) di Kabupaten Banyuasin. Studia Manageria: Jurnal Manajemen Pendidikan Islam, 2 (1). Setiyani, W. (2017). Kompetensi Sosial Kepala Sekolah Terhadap Pelaksanaan Manajemen Berbasis Sekolah. Jurnal Institut Agama Islam Negeri, (IAIN) Purwokerto, Indonesia.

Soedarmo, U.R., Herman, M. (2017). Kemampuan Manajerial Kepala Sekolah dalam Meningkatkan Prestasi Sekolah: Studi di SMP Negeri1 Cihaurbeuti Kabupeten Ciamis. IJEMAR, 1, (2).

Suhardan, D. (2010). Supervisi Profesional Layanan dalam Meningkatkan Mutu Pembelajaran Dierra Otonomi Daerah. Bandung: Alfabeta.

Suryana, A. (2004). Orientasi Kepemimpinan Kepala Sekolah dan Kreativitas Dewan Sekolah serta Upayanya dalam Peningkatan Mutu Sekolah. Jurnal Administrasi Pendidikan, 2 (2). 
Tolchah, M. (2015). Dinamika Pendidikan Islam Pasca Orde Baru. Yogyakarta: Pelangi Askara.

Wahyudi. (2009). Kepemimpinan Kepala Sekolah dalam Organisasi Pembelajar (Learning Organisasi). Bandung: Alfabeta.

Yahdiyani, N.R., Muna, A.R., Nurjannah, S., \& Wahyuni, S. (2020). Peran Kepemimpinan Kepala Sekolah dalam Meningkatkan Kualitas Peserta Didik di SDN Martapuro 2 Kabupaten Pasuruan. EduPsyCouns Journal, 2 (1). 
(20) 